\title{
A View of Anthropology from the Canadian Semi-Periphery
}

\author{
Bruce Granville Miller ${ }^{1}$
}

\begin{abstract}
Submetido em $1^{\circ}$ de junho e aprovado em 8 de julho de 2018.
\end{abstract}
\begin{abstract}
This paper compares Canadian, and in particular, British Columbian, and Brazilian anthropologies, and how they relate to the current political struggles of Indigenous peoples. I begin by arguing that, despite a semi-peripheral positioning of Canada in relation to the United States and other centers of academic theorizing and the training of faculty members, there is a distinctive history of the practice of anthropology in British Columbia based on a dialogical, grounded approach. Brazilian anthropologists and British Columbians have in common that they have long since moved past studies of acculturation, ethnicity, and interethnic friction into newer approaches, and I emphasize the factors influencing how these have emerged. Using examples from my own Department of Anthropology at the University of British Columbia and my own practice, I point to significant differences in the political position of Indigenes in the two countries, and in the national legal systems, and consequently, how anthropologists work with Indigenes and theorize their interactions. Anthropologists' role as expert witnesses in Indigenous litigation is structured differently than in Brazil and in British Columbia enables a deep and long-term connection between anthropologists and Indigenous communities. I note that sociocultural anthropology in British Columbia, unlike Brazil, is linked with archaeology and biological anthropology in work with Indigenes, which shapes the interaction and research questions.
\end{abstract}

Keywords: British Columbia. Canada. Brazil. Anthropology. Indigenous people Acculturation. Comparisons

Resumo: Este artigo compara a antropologia canadense, em particular a da Columbia Britânica, e a brasileira, com o objetivo de analisar o modo como elas se relacionam com as atuais lutas políticas dos povos indígenas nestes contextos. Começo argumentando que, apesar de um posicionamento semiperiférico do Canadá em relação aos Estados Unidos e a outros centros de teorização acadêmica e treinamento de professores e pesquisadores, há uma história distinta da prática da antropologia na Colúmbia Britânica, baseada em uma abordagem dialógica e situada localmente. Os antropólogos brasileiros e da Colúmbia Britânica têm em comum o fato de já terem passado pelos estudos sobre aculturação, etnicidade e fricção interétnica para novas e mais recentes abordagens, onde enfatizarei os fatores que as influenciaram e deram forma. Usando exemplos do meu próprio Departamento de Antropologia na Universidade da Colúmbia Britânica e minha própria prática, aponto para diferenças significativas na posição política dos indígenas nos dois países, e nos sistemas jurídicos nacionais para, consequentemente, indicar como os antropólogos trabalham com os indígenas e teorizam sobre suas interações. O papel dos antropólogos como peritos em litígios indígenas é estruturado de maneira diferente no Brasil e na Colúmbia Britânica, possibilitando uma conexão profunda e de longo prazo entre antropólogos e povos indígenas. Observo que a antropologia sociocultural 
na Colúmbia Britânica, ao contrário do Brasil, está ligada à arqueologia e à antropologia biológica no trabalho com os indígenas, o que molda as questões de interação e pesquisa.

Palavras-chave: Colúmbia Britânica. Canadá. Brasil. Antropologia. Povos Indígenas. Aculturação. Comparações.

The notion of a Canadian periphery (or semi-periphery) is an intriguing one because the relationship to the hegemon, the United States, is so close and interwoven with Canadian affairs. Despite this, Canadian anthropology has developed in highly distinct ways, reflecting the available resources, influences from the Commonwealth world, and the particular evolution of Canadian Indigenous peoples' circumstances. This volume point to ways in which anthropologists from two countries, Canada and Brazil, have influenced each other, in particular in relation to our role in Indigenous peoples' actions to advance their own political, economic, and cultural causes. This requires some teasing apart. First, I consider Canadian anthropology in British Columbia on the west coast as an entity, if one can make such a claim, and then I take up my own relationship to Brazil and Brazilian anthropology and governance in an effort to provide nuance to the discussions of national anthropologies. I should reveal at the outset that I am not a Canadian anthropologist of Indigenous peoples of Brazil; I am something different. Instead, I am a Canadian anthropologist whose work in Brazil has been to learn something of Brazilian anthropology, and how the state operates (in particular the Fundação Nacional do Índio or FUNAI, the Indigenous Affairs Agency in Brazil, and the Ministério Público no Brasil, a government agency with the power to sue other ministries on behalf of government) in relation to the Indigenous peoples. I am not an expert on Brazilian Indigenous people, even though a Brazilian ambassador to Canada described me this way on several public occasions. I'm interested in what we can learn comparatively, one of the goals of the present project. In fact, a major reason for my own work in Brazil has been to widen and deepen the ways in which Indigenous people's experiences can be understood. The differences between the two countries can create and enhance researchable variation.

Baines (2012: 216) pokes a finger in the eye of Canadian anthropology rhetorically, citing notions held by others of a neo-colonial mentality of Anglophone 
Canadian anthropology and derived in part from the large percentage of those holding posts in Canadian anthropology departments holding PhDs from outside the country. As a consequence, in this line of thinking, there can be no "local tradition." This is far from the case, as I hope to show, and this is not really Baines' own position. In fact, Canadian (and British Columbian) anthropology has a distinctive tradition of deep field and interdisciplinary engagement.

Baines also finds, in his study of the anthropological traditions of Canada, Brazil, and Australia, that Brazilian anthropology focuses on "the interethnic relations of these peoples within the context of the national state, in addition to studying internal aspects of indigenous societies, tradition firmly established by Darcy Ribeiro and finding its principal theoretical mentor in Roberto Cardoso de Oliveira in his notion of "interethnic friction" in the early 1960's" (Ibid., 219). Cardoso de Oliveira, he writes, moved Brazilian ethnology away from acculturation studies (Ibid.). Something similar happened in British Columbia at about the same time. The massive set of studies of the situation of the Indigenous peoples of British Columbia commissioned by the Canadian Department of Citizenship and Immigration in 1954, and carried out by Harry Hawthorn and his colleagues at the University of British Columbia, was published in 1958 under the title The Indians of British Columbia and represents the high-water mark of acculturational studies in B.C. Since then, there has been recognition that the Indigenous population is not simply going to disappear from view. Barnes properly connects this change to the significance of economic development of the Canadian north and the impacts on Indigenous people there (Ibid., 223).

Further, Baines (2012: 26) cites Ramos (1990) concerning the inadequacy of anthropological approaches, including acculturation, ethnicity, and interethnic friction to respond to the growth of the political power of Indigenes, leading to dialogical methods. Since Indigenous peoples now number some $5 \%$ of the Canadian population, with a powerful group of youth activists, roles must be rethought. Citing Oliveira, Baines writes, "The old role of the anthropologist as intermediary and spokesperson between indigenous peoples and the state has been replaced by that of an assessor who establishes a dialogical posture of political commitment with the indigenous people (s)he works with, respecting 
their opinions and decisions (Oliveira, J. p. 2009)." I think, instead, that both roles coexist and the intermediary is not entirely gone. To make this point, and to reveal the distinctive character of anthropology in British Columbia I start at the beginning. Note that while I emphasize the role of the department of anthropology at $\mathrm{UBC}$, there are other major programs, such as at Simon Fraser University, the University of Victoria, and University of Northern British Columbia.

\section{Canadian/British Columbian anthropology}

British Columbian anthropology had a nineteenth century origin; Franz Boas began his Northwest Coast research in the 1880s and the Canadian Geological Survey employed scholars to carry out ethnographic work with West Coast Indigenous peoples (this latter phrase refers to Indigenous communities on Vancouver Island). Initially, anthropology was housed in museums, and much later a university system emerged, with the University of British Columbia (UBC) anthropology department established in 1947 under a New Zealander, Harry Hawthorn. Professors Elvi Whittaker and the late Michael Ames write in their study of UBC anthropology, 1947-80s, "Early in his tenure as department head, Hawthorn engaged other faculty and students in a number of applied interdisciplinary research projects that gained international attention... These major projects clearly announced the department's Canadian orientation and were researched and written with policy issues in mind... Hawthorn wrote later, "Perhaps above all I wanted to put anthropology to good use." Working relationships with First Nations artists and band councils were also established during those early years. Once settled at the university, Harry and Audrey Hawthorn visited the different regions of British Columbia to meet people, especially members of First Nations (Hawthorn 1993, 6-7) (Whittaker and Ames 2006: 160)."

Whittaker and Ames add, "By the 1970s the [UBC] department had established its primary areas of emphasis: an Americanized four-field model in anthropology; in anthropology, there was a concentration on the Northwest Coast, South Pacific, East and South Asian culture areas" (Ibid., 162). Whittaker and Ames took note of the national composition of the faculty, "The large influx of young American-trained faculty from 
the politically active US campuses brought their political culture with them . . . Academically the department had an American, British, and French focus, in degrees awarded, nationalities of individual professors, and theoretical ideologies favoured" (Ibid., 163).

Still later, UBC hired Canadian-trained anthropologists, including Julie Cruikshank in 1990 and John Barker in 1988. I was hired in 1990, and trained at Brown University and Arizona State University, both in the U.S. Since then other Americans, some British and several Canadians have been hired. The persistent theme at UBC, however, for all of us, independent of where we were trained, was engagement and the department decided around 2014 that the collective identity was of "grounded" researchers, whose research questions arose primarily from pressing questions derived from work with living populations (see Thom 2017). It is incorrect to say, however, that UBC anthropology is simply applied as opposed to theoretical or that these stand two in opposition. In addition, the approach at UBC is similar to that taken in other departments in Canada, and might be said to characterize Canadian anthropology generally. Further, the approach at $\mathrm{UBC}$ reflects the highly dynamic situation regarding Indigenous rights and their place in Canadian society. Especially over the last two decades First Nations have achieved a significant level of self-governance along with key legal victories concerning the Crown's obligation to consult with them concerning economic development and the Crown's fiduciary obligations. (I provide more details about this later). Yet, the UBC approach also predates all of these developments.

French influences declined and the department remained Boasian in the sense of having four fields, although museum anthropology was promoted to a fifth distinct field. (See Kew 1993 and 2017 for published papers on anthropology at UBC and its relationship to Firsts Nations).

Simon Ottenberg, a retired University of Washington (USA) professor of anthropology, pointed to differences in approach between American and Canadian anthropologies, even those as geographically close as Vancouver and Seattle. He writes that at the University of Washington "over the years, professors with interests in indigenous Northwest groups were systematically forced out of the Department, replaced 
by scholars with interests in Asia, Africa, and elsewhere ...." (2014:1). Administrators of this American university believed there was more prestige associated with studies abroad than with the local Indigenes, a very different approach than the tradition of longterm, detailed, grounded work with local indigenes which characterizes British Columbia anthropology. (This is not to say that UBC scholars don't carry out research abroad. Many do). It may also reflect the relative levels of available resources for research in Canada and the United States; it is cheaper to work locally. Finally, the research tradition in British Columbia reflects a sense of concern and obligation to the province and to the original inhabitants, which Ottenberg writes is missing at the University of Washington.

A point of major difference with Brazilian programs is the close engagement between sociocultural anthropologists and archaeological and biological anthropologists. As an ethnographer of Coast Salish communities, for example, which comprises part of my research agenda, I work regularly with archaeologists and one could say that we study the same sort of issues (identity, social organization and so on) with the same communities but on different time scales. More recently, I have found utility in adapting archaeological times scales in studying the persistence of political practices among Coast Salish, inverting the practice, identified by archaeologists as potentially problematic, of assuming ethnographic practices in deep time (Grier 2007). This approach is built into a recently published tribal Atlas (Miller et al. 2018). I began my work with Coast Salish communities as a graduate student, in part carrying out research for the communities which fed into treaty litigation, but while also studying the transformation in the systems of gender and politics. Many archaeologists have a similar history of initiating their engagement.

We, the archaeologists and sociocultural anthropologists, both work directly with community members and I established an on-site graduate ethnographic fieldschool with the Stò:lô Nation, located on the Fraser River in southern British Columbia. My students and I worked alongside archaeologists Michael Blake of UBC, Dana Lepofsky of Simon Fraser University, and many others, and with Coast Salish community members, sometimes walking the fields or along rivers looking at archaeological sites and considering issues such as what they mean to the contemporary communities or how they can be preserved. I 
also work with biological anthropologists such as Darlene Weston of UBC on repatriation of ancestors (skeletal remains) to communities, together with isotope analysis of diet, and biological analysis of the time of death, sex, and other features. Our relationships with First Nations today requires this cooperation between sub-disciplines of anthropology, at least as it is understood at $\mathrm{UBC}$, in order to answer the sort of research questions which arise collectively. In my experience, the relationship between the praticitioners of the different subdisciplines of anthropology has been harmonious and current graduate students are generally cross-trained, meaning they learn archaeological techniques but also theories of oral history, for example. Differences may arise concerning topics such as the rise of chiefly systems and social complexity but these lead to lively debates.

Because several anthropologists at UBC and other Canadian universities work closely with First Nations and other Indigenous peoples (of which there are three categories in Canada; First Nations, Inuit, and Mètis), we often give expert testimony in legal settings concerning Indigenous rights, fisheries, treaties, and other topics. My own litigation work has entailed representing to the court why a child chosen by the family for spiritual training should live with the grandmother, how to compensate a family financially for the wrongful death of the family ritualist who had little income (when ordinarily compensation is a multiplier of prior income), how a Crown (the federal Department of Justice) witness misrepresents Indigenous oral history evidence, and many other topics. I have made this work one of my areas of analysis and theorizing, particularly human rights and oral evidence, which benefits from being on the inside of litigation, where I can see clearly how legal and anthropological concepts are marshalled for use in court. This is where applied anthropology and theoretical anthropology overlap. One of my books, for example, Oral History on Trial (2007) is directly concerned with oral history evidence given by Indigenous peoples following a Canadian Supreme Court decision in Delgamuukw, 1997, that oral history evidence would have the same footing as written history. Publication of this book provided the court an idea of what an Indigenous oral historian might be and how poorly formed Crown theories improperly have served to disqualify this sort of testimony. The book has led to consultation with First Nations around Canada. Concern with legal processes is an area that both Canadians and Brazilians 
now share, arising from research experiences with Indigenous peoples, particularly in Brazil with the studies of Índios in incarceration. Charles Menzies is another in the UBC department of anthropology with considerable experience in this field, along with myself. This is the anthropological world I inhabit at home.

An additional comparative issue is the arrangement of academic fields in the two countries. In my experience, I have found much more interest in comparative studies in Brazil and national traditions of anthropology; hence this volume. Exceptions to this generalization are the books edited by Julia Harrison and Regna Darnell on Canadianist anthropology (2006) or Darnell and Frederic Gleech (2014). Yet, Canadians have not created programs built on comparison as in Brazil. The comparisons drawn by anthropologists in Canada are typically between the Indigenous peoples in the Englishspeaking Commonwealth countries, especially Australia and New Zealand. Oddly, Canadians are slow to draw comparisons between the Indigenous peoples of Canada and with American Indians, despite the fact that many Indigenous nations overlap the international border. This, I think, reflects an interest, perhaps unconscious, in distancing oneself from U.S. issues and domination. My own work builds in part on the fact that the Coast Salish Indigenous peoples I work with reside in the U.S. and Canada and are the same people culturally but have had different histories of contact and have lived under different public policies, particularly since the international border dividing what became British Columbia and the State of Washington was created in 1846. I am able to use these differences to gain analytic purchase to study social features such as the organization of gender, political participation, and so on. Meanwhile, Brazilian anthropologists, such as Stephen Baines, have built on differences as well in their work in the Amazon in particular, and this is an important overlap in practice but not in institutional structure. At UBC, for example, we have no departments of comparative studies.

Another difference is that unlike Brazil, Canada has two official languages and two largely separate bodies of anthropologists (although there are French and English speakers in the Canadian Anthropology Society). Quebec draws the attention of Brazilian scholars, in part because of the perception of common Latin origins. Perhaps most important to a consideration of Brazil and Canada are the changing circumstances 
facing Indigenous peoples in the two countries. British Columbia has few treaties, highly unusual in the English-speaking world of former colonies, and is now undergoing a glacially slow effort to create treaties. And, highly significant struggles are underway concerning First Nations rights to be consulted and efforts to resist further destruction of the environment through construction of oil fields, pipelines, and increased shipping and logging. To use an American phrase, it is "high noon" in British Columbia with intense political and legal fights between the Crown and First Nations. First Nations are now geared up with their own lawyers, researchers, and staff, to take on the challenges their forebears were unable to sustain. Brazilian Indigenous peoples appear to be making organizational progress in defending their own interests but seem to me to have not yet arrived at what might be viewed as a take-off point and so the work of anthropologists differs in significant ways. Note that in establishing the field school I mentioned in 1992 I met with the entire staff of five of the Stò:lô Nation in a trailer. Today, the Nation has over three-hundred employees running departments of health, social services, education, law, and others. There is very considerable development of self-government (including child-welfare, educational services and so on) among many First Nations of Canada, but particularly in British Columbia. This means that anthropologists often work with specific First Nations agencies, and through their now well developed protocols and concerning issues of their choice. Contact and work with Brazilian anthropologists has brought a different set of considerations.

\section{A Canadian Encounters Brazil and Brazilians}

Brazilian anthropologists first engaged me in asking my help in situating their own work in British Columbia; this included Stephen Baines - some twenty-five years ago - and Cristhian Teófilo da Silva (2005) in the last decade. These scholars were interested both in Canadian anthropology and the circumstances facing the Indigenous peoples in Canada. Later, I hosted a number of other Brazilians with similar interests, several of whom spent time as visitors at UBC. Among these were Gustavo Menezes and the late Daniel Brasil and his wife Barbara, also an anthropologist. Daniel Brasil completed a joint PhD with the University of British Columbia and the Universidade de 
Brasília (University of Brasilia), under the supervision of myself and Stephen Baines. I also hosted another set of anthropologists, representatives from the Ministério Público no Brasil in conferences in Vancouver. Some Brazilians were students in my classes such as Rodrigo Ferrari-Nunes, who did an MA under my supervision.

These exchanges both followed and led to my own visits to Brazil, where I taught at the University of Brasilia for a term and spoke with various officials of the Fundação Nacional do Índio. My trips to Brazil have ranged from Manaus to São Paulo and in between. In all of these places I spoke at universities and learned from colleagues there about their own work with Indigenous peoples including Indigenous students in my class or classes of others. On one occasion, I visited a Quilombo community with Daniel Brasil, located several hours outside of Brasilia, and spoke with community leaders about how they dealt with the problem of their territory falling into multiple political jurisdictions. (I should add, as an aside, that the very great differences in how universities are managed in the two countries is quite interesting, as is the role anthropologists play in university affairs. When I first came to the University of Brasilia, the very heated election for Reitor was underway. Groups of undergraduates excitedly crowded the hallways of the campus, preparing to vote. On two occasions, I met with presidents of public universities, one at the opening of a new building at which I gave the inaugural speech. I have almost never been able to meet the president of my own university and on one occasion an email I sent to the president was blocked by an administrator. I had to ask the faculty association to intercede. Canadian university presidents are most definitely not elected by faculty or by students. To quote the Russian saying about czars, they are mighty and far away).

A research question which has persistently interested me is: how do Indigenous peoples represent themselves in political life and in the legal system? Brazil is an interesting counterpoint because the Canadian system is an English common-law system and the Brazilian legal system derives from the civil law tradition, although I am informed that the system is moving slowly towards the other. A second point of distinction, and consequently a researchable issue, is the manner in which Indigenous people are understood in both popular culture and in the law. Relatedly, there are 
considerable differences between the processes of racialization in the two countries, with direct implications for the Índios, and which is a topic drawing academic attention.

Concerning law: Gustavo Menezes and I recently published a co-written paper about the common problems we face in presenting information to the court about Indigenous legal concerns; in his case largely criminal matters, and in mine, largely civil (Miller and Menezes 2017). A significant difference we noted is that Brazilian anthropologists, such as Menezes, a FUNAI employee, might be tasked by the court to present relevant social and cultural information for a particular criminal litigation. In Canada, the court generally has no role in assigning anthropologists to investigate (there are a very small number of exceptions to this), but rather the Crown hires its own experts and the Indigenous groups hire their own. This difference places anthropologists in quite a different stance relative to legal proceedings and in their relationship with Indigenous communities and people. And while I understand that Brazilian universities may restrict outside professional practice by the professorate, it is not the case in Canada, as I have indicated. I think that for Canadian anthropologists who have worked with particular communities over a long period and been contracted to represent them in court, a particular kind of deep relationship can develop. (I should add that an expert is accepted by the sitting justice to give testimony in the English common law system only to be useful to the court and experts cannot advocate for one side). Much of my understanding of contemporary Indigenous communities in Canada and the United States derives from these experiences of working in litigation with them (see Miller 2018, an Atlas for the Upper Skagit Indian Tribe, which reflects this engagement). In writing about legal issues as they affect the sovereignty and development of Indigenous nations, there is nothing quite like being on the inside over long periods.

Menezes and I noted the similarities of the circumstances facing Indigenous peoples in our two countries, particularly the bias, stereotyping, and racism which they face. We focused on the various ways in which the issues of concern to Indigenous peoples were transformed through legal processes, in effect, refracted by legal terminology and cultural understandings. Differences showed up here, too, and Menezes wrote: "It turns out that most law enforcement officers have labeled the Indigenous as integrated/acculturated based on very superficial elements, such as possession of identity 
documents, some knowledge of the Portuguese language, the use of clothing, and even mestizo physical appearance" (Miller and Menezes 2017: 392). He focused on the gap between the progressive Brazilian Constitution and the common reliance in the judiciary on dated law. "While some of this simplistic interpretation is supported by the Natives' own idiosyncrasies, it is also supported by Law 6001 of 1973, known as "the Indian Statute" (ibid.). Menezes clarified that Indigenes in this legal regime were regarded as isolated, in the process of integration or integrated and that the Indian Statute was based on notions of civilization.

Here a gap opens with Brazilian and Canadian law and, consequently, the work of anthropologists. Canadian practice doesn't generally leave any space for degrees of integration, although it did through the 1950s, and today relatively wealthy First Nations exist. The Musqueam, and two other First Nations in the Vancouver area, for example, have just claimed control over several hundred acres of prime city real estate which they intend to develop into more than a billion dollars-worth of housing. These bands are not, however, regarded as non-Indigenous by the Canadian Crown or any legal entity despite their clear integration into the regional economy. Anthropology in Canada, as I have noted, has taken a turn and the notion of the eventual assimilation and amalgamation of Indigenous peoples is now gone, although retained by some extremist right-wing scholars. We are finding new ways to work with these communities, no longer as their interpreters to the mainstream society nor as ethnographers of the ethnographic present, except in legal cases, where we must play this role. In my own case, and in that of many others, we are now focused on examining the region of interaction, the fraught relationships between mainstream institutions and the First Nations. As I have suggested, much of this concerns Indigenous law and Canadian law as it concerns Indigenous peoples. Here, in many instances, anthropologists work with legal scholars, some of whom are Indigenous.

But there is the other extreme in Canada, those communities whose circumstances are vastly different than that of the Musqueam, and in which groups of Indigenous people have no recognized nation, even though members may individually have recognition as Status Indians. It is a distinct form of invisibility (see Miller 2003). I currently work with two such bands in the greater Vancouver area, the Hwlitsum and the Pender Harbour 
groups. They both have struggled with the Crown to gain legal standing so that they can fit into a legal requirement deriving from case law that they be consulted in projects (hydro, for example) developed in their historic territories. Here I found some interesting comparisons with the Indigenous community in the Brasilia area, Santuário dos Pajés. This community, as I understand it, is composed of descendants of Indigenous people largely from the northeast who were brought in to help build the new capital city. Members of the small community have told me that they have faced onslaughts by developers. But meanwhile, the community moved along some steps towards recognition under the Brazilian demarcation program and are the first such group living outside of their historic territories to do so. The community has recently received recognition from the Governement of the Federal District but whether the final Presidential signature will be granted seems highly unlikely under the current regime. These cases in the two countries both raise the issue of what recognition by the state means, how it is procured, and what benefits might be connected.

In Brazil, the issue of Quilombo communities (settlements whose members in part are descendents of slaves who escaped from capativity in the centuries before the prohibition of slavery) raises similar concerns which Daniel Brasil took up in his research and his published book. In a larger sense, the issue of invisibility which the communities in consideration here face, enables one to look at issue of what are Indigenes from another angle. How do they relate to the mainstream population of the two countries? In North America, the new field of Indigenous Studies has found its feet and the young scholars, generally of Indigenous heritage, are developing their own methodologies, their own understandings of data, and their own preferred important scholarly texts. The creation of the Native American and Indigenous Studies Association (NAISA) recognizes this fact. Part of this movement, echoed in anthropology, has been the developed of critical theory which supposes that any form of recognition by the state is harmful and erodes Indigenous culture. A First Nations student in one of my courses recently told me that I was "bad" for writing Oral History on Trial, and that to her the hard work of representing Indigenous rights in court was counterproductive because formal recognition by Canada itself is destructive and erases Indigenous culture. 
Related to this development is the idea that Indigenous communities can now largely control the terms on which scholars and the academy can work with them. This means, for example, deciding which archaeological sites might be investigated and the requirement of co-management of cultural resources. It also concerns how Indigenous communities respond to bureaucratic categories. Daniel Brasil's PhD dissertation (2015) considered the ways in which various sorts of communities, some which could be considered Indigenous, manage their complex relations with the state. He created the concept of "underdogs," meaning those communities which strategically maneuver within state categories, aware, however, that they might not or perhaps cannot escape the manipulation by state processes which subvert their autonomy. This work was based on fieldwork in Brazil with Quilombo communities in the process of considering whether they wished to be included in the Quilombo bureaucratic category; in Canada with First Nations including non-state recognized groups; and in Cuba, with Afro-Cuban local groups hoping to assert some local control. Brasil's work reflects Brazilian interests in comparative projects (and his UnB department was a comparative studies unit) and both Canadian and Brazilian theoretical interests in the boundaries of Indigenous identities. Further, Brasil's scholarship was founded in the study of how categories are constituted bureaucratically and how subordinated communities are engaged in dialogue with the state. Brasil's work is also of interest because, unlike Canadian anthropology on the whole, he merged studies of Indigenous peoples with other sorts of marginalized peoples, including those of African descent.

The notion that engagement with the state might be problematic is not new, nor reserved to academic commentary. A Métis doctoral student, Richard Ouellet (2016), I recently supervised, is a member of a community which refused to identify itself in any way (for example, as Métis) because the elders have long thought that a relationship with Canada would be destructive, even though they had been removed from the homes in an area that is now Jasper National Park in Alberta, nestled in the Rocky Mountains. Meanwhile, Brazil has slowly labored towards and away from the demarcation of Indigenous lands by FUNAI. Lands, I was told by a FUNAI vice-president, that with the help of anthropologists, land will be demarcated, outsiders removed, and Indios will 
undergo economic development. But strong resistance to this process is evident in federal politics, in the judiciary, and in the public. In Brasilia in 2007, during a stay at UnB, I spoke with Índios picketing outside the Supreme Federal Court for the retention of the demarcation of their lands, an issue which had been placed into legal jeopardy. Alongside them were signs put up by rice farmers who were counter-picketing and claiming their rights to farm.

In both Brazil and Canada there is an impulse towards and away from recognition, both as a legal right and as a form of visibility, and in academic writing and in Indigenous community political activity. The responses of anthropologists in the two countries share a general theoretical shaping, but the circumstances of our two systems of law and the state of institutional integrity and governmentality in the two is quite different. Consequently, our engagement with Indigenes is shaded in different ways. In addition, the circumstances of the discipline of anthropology is quite different, also creating differences in our efforts. While anthropology in Canada might be marginalized in universities intent on developing financial relationships with industry and promoting STEM programs instead of social sciences, the discipline is not directly under the gun of the government. The Brazilian Anthropology Association recently emailed,

"The Brazilian Anthropological Association (ABA) is currently being intimidated by representatives of the National Congress who represent the interests of the Agribusiness in the Parliamentary Commission of Inquiry (CPI) installed to investigate the National Indian Foundation (FUNAI) and the Institute of Colonization and Land Reform (INCRA). The aim of the representatives, particularly of Nilson Leitão (PSDB), is to minimize and ridicule the professional and technical work of anthropologists who elaborate reports, under State regulations, that are crucial for the recognition of Indigenous and Quilombolas (Afro-Brazilian traditional communities) lands. For that reason, ABA would like to ask for the support of fellow anthropologists, social scientists, practitioners, organizations etc., around the World that are able to endorse the high standards of the Anthropological practice in Brazil."

Donna Patrick, then President of the Canadian Anthropology Society (CASCA), following from my prompting, wrote officially on behalf of CASCA in support of ABA 
(emails, 2017-02-12). The situation in Brazil potentially poses restrictions, both those imposed externally and those imposed internally, on academic work which we don't have in Canada. The high standard of work done in Brazil is threatened by political circumstances and the same is generally not true in Canada. The situation in Canada is considerably different under Prime Minister Trudeau than under his predecessor, Harper. One example makes this point: as a Board member of the Museum of Vancouver I supported a grant application for funding an exhibit which concerns Musqueam's long-term residence of thousands of years in what became the city of Vancouver. We were awarded the top score in this national funding competition but were denied the funds through the intervention of the Harper regime. Those involved, the museum staff and myself, could only conclude that it was "pay-back" for the successes Musqueam has achieved in federal courts. Today, in contrast, the federal minister of the Department of Justice, Jody Wilson, is a First Nations lawyer appointed by Trudeau.

Time will tell how these circumstances will affect anthropological practice. Meanwhile, in the United States, the current political climate of intimidation and denial there of the basic social circumstances of racism and oppression, which is a primary focus of anthropology today, will have its own effects, perhaps further distancing Canadian anthropology from that of the Americans. One could anticipate that in both Brazil and the United States, some anthropologists would find it convenient to shift research to noncontentious topics and ones which could find funding in a state controlled by populist, anti-intellectual politicians and bureaucrats. Conversations I have had with Brazilian anthropologists who weathered the period of military dictatorship suggests that Brazilians will continue to find ways to advance theory and empirical findings which reveal the fissure lines of society there. I am less sure of American colleagues.

In this paper, I have attempted to show the history of the creation of a distinct, British Columbia, Canada, style of anthropology which has its focus on dialogical methods and direct, long-term relations with Indigenous communities and peoples. Rather than “cookbook" ethnographies of Indigenous communities regarded as isolates, anthropology is now largely focused on anthropologies and publications directed to particular social issues, such as the legal systems and the ways they impinge on Indigenous lives, or 
barriers to health care. These studies are situated on the borderlands of the mainstream society, the state, and the Indigenous communities and the theorizing reflects this. In our efforts to operate as "grounded" scholars, we have resisted the temptations which Ottenberg details for high-status American universities, although we have paid a price for this. It sometimes puts us in disagreement with Deans and other officials who wish to promote heavily funded grand theorizing research which many of us see as regressive, even $19^{\text {th }}$ century in orientation, such as cultural evolutionary studies based on cladistics, studies of altruism, and so on. To many of us, these approaches appear to have no utility in the real world and to be uninformed in their premises.

The founder of the anthropology department at UBC, Harry Hawthorn, developed a department which foregrounded studies of real utility, and we have continued on this path, but without teleological assumptions about the eventual assimilation of Indigenous peoples. And, the origin of the professorate, New Zealand, American, British, or Canadian, has made little difference. An important Canadian development is that federal funding for research in fields outside of anthropology sometimes requires anthropological contributions. These factors make our anthropology a little different than that practiced in Brazil, where there is an apparent tension between the importance placed on theorizing and grounded work in community. Here, I have treated Brazilian anthropology as a monolith, and I realize that it is not and that there are regional and other forms of difference internally, but clearly the theorizing-grounded tension is an important one.

\section{References}

BAINES, Stephen Grant. Social Anthropology with Indigenous Peoples in Brazil, Canada and Australia: A comparative approach. Vibrant v.9 n.1, p. 210-238. 2012.

BRASIL, Daniel Rodrigues. The Underdog World. PhD Dissertation, Department of Anthropology, University of British Columbia, 2015.

DARNELL, Regna and GLEACH, Frederic W. Anthropologists and their Traditions across national border: histories of anthropology annual volume 8, Lincoln, Nebraska: University of Nebraska Press, 2014.

DARNELL, Regna and HARRISON, Julia, Historicizing Canadian Anthropology, Vancouver: University of British Columbia Press, 2006. 
DA SILVA, Cristhian Teófilo Anthropology and Ethnicity's Interplay Among First Nations in Canada: The Case of Quebec. The Canadian Journal of Native Studies XXV, 2(2005):553-569.

GRIER, Colin. Consuming the Recent for Constructing the Ancient: The Role of Ethnography in Coast Salish Archaeological Interpretation. In Miller, Bruce Granville, "Be of Good Mind:" Essays on the Coast Salish, p. 284-307. Vancouver: University of British Columbia Press, 2007.

HAWTHORN, Harry, Hawthorn, H.B., Belshaw, C.S. and Jamieson, S.M. The Indians of British Columbia, a Study of Contemporary Social Adjustment. Toronto: University of Toronto Press, 1958.

KEW, J. E. Michael. Anthropology and First Nation in British Columbia, BC Studies 10, p. $78-195,1993$.

. Reflections on Anthropology at the University of British Columbia. B.C. Studies 193, p. 163-185, 2017.

MILLER, Bruce Granville. Invisible Indigenes: The Politics of Non-recognition Lincoln: University of Nebraska Press, 2003.

. ed. Upper Skagit Indian Tribe Historical Atlas. Sedro-Woolley, Washington: Upper Skagit Tribe of Indians, 2018.

MILLER, Bruce Granville, and MENEZES, Gustavo. Anthropological Experts and the Legal System: Brazil and Canada, American Indian Quarterly, v. 39, n.4., p. 391-430, 2015.

OTTENBERG, Simon. Experiences in the University of Washington Anthropology Department, 1955-1991. Journal of Northwest Anthropology, v. 49, n. 1, 2014.

OUELLET, Richard. The life and death of the Council of Elders of the Descendants of Jasper Park. PhD dissertation, Interdisciplinary Studies, University of British Columbia, 2016.

RAMOS, Alcida Rita. "Ethnology Brazilian style." Cultural Anthropology, 5(4): 452457, 1990.

THOM, Brian. The Contemporary Coast Salish: Essays by Bruce Granville Miller. Bruce Granville Miller and Darby C. Stapp, Editors, BC Studies, n. 195, p. 158-159, 2017.

WHITTAKER, Elvi and AMES, Michael. Anthropology and Sociology at UBC from 1947 to the 1980s. In Historizing Canadian Anthropology: Julia Harrison and Regna Darnell, ed., p. 157-172. Vancouver: UBC Press, 2006.

\section{Notes}

${ }^{1}$ Full Professor of Anthropology at UBC, University of British Columbia, Vancouver, Canada. bgmiller@mail. ubc.ca 